\title{
Gezondheidseconomie als wetenschappelijk vakgebied
}

Citation for published version (APA):

Leidl, R. M. (1993). Gezondheidseconomie als wetenschappelijk vakgebied. Maastricht University. https://doi.org/10.26481/spe.19931021rl

Document status and date:

Published: 21/10/1993

DOI:

10.26481/spe.19931021rl

Document Version:

Publisher's PDF, also known as Version of record

\section{Please check the document version of this publication:}

- A submitted manuscript is the version of the article upon submission and before peer-review. There can be important differences between the submitted version and the official published version of record.

People interested in the research are advised to contact the author for the final version of the publication, or visit the DOI to the publisher's website.

- The final author version and the galley proof are versions of the publication after peer review.

- The final published version features the final layout of the paper including the volume, issue and page numbers.

Link to publication

\footnotetext{
General rights rights.

- You may freely distribute the URL identifying the publication in the public portal. please follow below link for the End User Agreement:

www.umlib.nl/taverne-license

Take down policy

If you believe that this document breaches copyright please contact us at:

repository@maastrichtuniversity.nl

providing details and we will investigate your claim.
}

Copyright and moral rights for the publications made accessible in the public portal are retained by the authors and/or other copyright owners and it is a condition of accessing publications that users recognise and abide by the legal requirements associated with these

- Users may download and print one copy of any publication from the public portal for the purpose of private study or research.

- You may not further distribute the material or use it for any profit-making activity or commercial gain

If the publication is distributed under the terms of Article $25 \mathrm{fa}$ of the Dutch Copyright Act, indicated by the "Taverne" license above, 


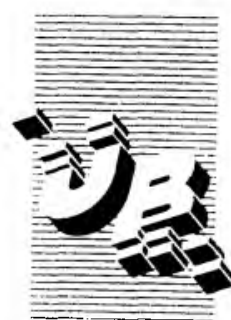

De uitleentermijn verstrijkt op:

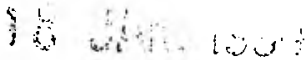

10 JAH. 1996

$-6.1909$

$\therefore \quad \div \quad \therefore \quad 2$

Ripksuniversılti Limburg

Posibus 616

6200 MO Maastrıch!

Gelieve deze publicatie tijdıg te retourneren of (telefonisch) verlenging van de uitleentermijn aan te vragen

UNIVERSITEITSBIBLIOTHEEK RU LIMBURG

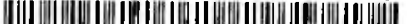




\section{Gezondheidseconomie}

\section{als wetenschappelijk vakgebied}

Rede uitgesproken bij de aanvaarding van het ambt van gewoon hoogleraar in de economie van de gezondheidszorg aan de Rijksuniversiteit Limburg op donderdag 21 Oktober 1993

door

Dr.oec.publ. R.M. Leidl 
Dibiomonar

F. 1. ingtio 


\section{Mijnheer de Rector Magnificus, dames en heren,}

Elke economische beschouwing begint met het verschijnsel van de schaarste: de beschikbare hulpbronnen zijn onvoldoende om alle bestaande behoeften te bevredigen. Het behoeft tegenwoordig nog amper toelichting, dat ook in de gezondheidszorg schaarste bestaat en dat er vele mogelijkheden zijn om de schaarse hulpbronnen te benutten. De wetenschappelijke behandeling van het vraagstuk van de schaarste en de keuzemogelijkheden tussen alternative wijzen van gebruik van hulpbronnen vormen een kernthema in de economische analyse. Het lijdt geen twijfel dat de economie zich ook met vraagstukken betreffende de schaarste in de gezondheidszorg kan bezighouden.

is de economie echter wel noodzakelijk voor een wetenschappelijke behandeling van gezondheid en gezondheidszorg? Voor de gezondheidszorg is gemakkelijk aan te tonen van wel, omdat zij ook als een productieproces kan worden opgevat: met hulpbronnen zoals de arbeidstijd van een specialist of een MRI wordt een bepaalde hoeveelheid zorg tot stand gebracht of geproduceerd. Het resultaat van deze zorg - de tot stand gebrachte verbetering van de gezondheid - kàn maar moet daarbij niet in beschouwing worden genomen. Een beschouwing over de zorgverlening zonder daarbij rekening te houden met de economische componenten ervan zou tot gevolg hebben dat een belangrijke dimensie over het hoofd wordt gezien. Economische analyses vormen dus een noodzakelijk bestanddeel van het onderzoek naar de gezondheidzorg.

Omdat de zorgverlening tot gezondheid bijdraagt, geldt de economische analyse tevens als een noodzakelijk onderdeel van onderzoek dat de gezondheid zelf als object heeft. Gezondheid wordt voorts bepaald door andere factoren waarover eveneens economische vragen kunnen worden gesteld. Een voorbeeld hiervan betreft de samenhang tussen de algemene levensstandaard, uitgedrukt als het inkomen per hoofd van de bevolking, en de meest harde indicator voor gezondheid, namelijk mortaliteit. Men vindt een positieve correlatie tussen beide variabelen wanneer men de geïndustrialiseerde landen met de landen van de Derde Wereld vergelijkt of wanneer men de landen in West-Europa vergelijkt met die in Oost-Europa. Zoals bekend, is de samenhang in de geïndustrialiseerde landen niet zo eenduidig en hier is verdere analyse vereist. Gezondheid en gezondheidszorg kunnen, zo luidt de conclusie, niet volledig en adequaat worden geanalyseerd indien de economische aspecten ervan buiten beschouwing blijven. 
In het verdere vervolg van mijn rede wil ik $U$ door middel van een aantal voorbeelden met enkele onderdelen van de veelzijdige gezondheidseconomie bekend maken. We beginnen met een terugblik op het begin en de wortels van het vakgebied. Daarna volgen een definitie van het vakgebied alsmede een discussie over de methodische en disciplinaire relaties van de gezondheidseconomie. In het derde deel komen enkele thema's uit het lopende onderzoeksprogramma aan de orde. Een eerste voorbeeld betreft de economische gevolgen van HIV en AIDS; het tweede voorbeeld gaat over de gezondheidszorg in de EEG.

\section{Begin en wortels van de gezondheidseconomie}

Er bestaat niet zoiets als een bijzondere gebeurtenis of publicatie die het begin van de gezondheidseconomie markeert. In de moederdiscipline, de economie, treedt zij voor het eerst in 1951 duidelijk naar buiten. In dat jaar publiceerde de wellicht beroemdste Vereniging van Economen, die American Economic Association, in de proceedings van haar jaarlijkse bijeenkomst bijdragen over twee sessies die gingen over de "Economics of Medical Care". De discussie concentreerde zich toen overigens nog niet op het vraagstuk van de kostenbeheersing; de vraag naar bijvoorbeeld een voldoende aanbod van voorzieningen kreeg meer belangstelling. De gezondheidseconomie als wetenschappelijk vraagstuk is dus niet, zoals vaak wordt beweerd, een resultaat van de explosieve kostenontwikkeling in de gezondheidszorg. Natuurlijk hebben de kostenproblemen later wel in sterke mate tot ontwikkeling en verbreding van het vakgebied bijgedragen.

Een tweede Amerikaanse wortel gaat terug naar de Public Health traditie. Zo beschikte de School of Public Health van de Universiteit van Michigan al in 1944 over een bureau "Public Health Economics". Dit bureau gaf een gelijknamig tijdschrift uit dat zich met overheidsprogramma's op het gebied van de gezondheidszorg, met vragen over de organisatie en financiering van de gezondheidszorg en met de analyse van de prestaties van de ziekenhuizen bezig hield (Mushkin 1958) - allemaal thema's die ook in de huidige gezondheidseconomie van belang zijn.

Een nog verder teruggaande historische ar.alyse zou zeker nog meer voorlopers aan het licht brengen. Ik wil mij tot drie voorbeelden beperken. Zij leggen historische verbindingen bloot tussen de gezondheidseconomie en het ontstaan van de sociale zekerheid, de waardering van het menselijk leven en de problemen van de bedrijfsvoering in ziekenhuizen. 
Beginnen we met het ontstaan van de ziektekostenverzekering. Al in de middeleeuwen hadden de gilden voor hun leden in geval van ziekte bepaalde vormen van ondersteuning georganiseerd. Later ontwikkelden zich hieruit vrije solidariteitsgemeenschappen, de zogenaamde hulpkassen. Vanwege het geringe aantal leden bleken deze hulpkassen vaak niet in staat om het optreden van grote schadegevallen financieel te dekken. Dit probleem van de groepsgrootte manifesteerde zich in de vorige eeuw in Duitsland, Engeland en Frankrijk (Herder-Dorneich 1981). In het voorbeeld van Duitsland - waartoe ik mij hier zal beperken - werd toen eerst een verzekeringsplicht voor beroepsgroepen ingevoerd die later tot de gemeenten werd uitgebreid (ibidem). Tenslotte bracht Bismarck in 1883 de eerste algemene ziektekostenverzekering voor arbeiders tot stand. Deze verzekering vormde de eerste peiler van een stelsel van sociale zekerheid. Kort daarna volgden een ongevallen- en pensioenverzekering. Politiek gezien kwam de sociale verzekering tot stand in een debat tussen Bismarck en de Sozialdemokraten.

De sociale zekerheid voor de arbeidersklasse, die als gevolg van de industrialisering was ontstaan, vormde ook onderwerp van een wetenschappelijke discussie tussen economen. Als forum voor deze discussie diende in het bijzonder de zogeheten "Verein für Socialpolitik". In de oproep tot oprichting van deze vereniging werden economische problemen van de gezondheidszorg ook als thema genoemd. In die tijd werd echter nog vooral over de verhouding tussen werknemers en werkgevers, over de wetgeving inzake fabrieken en over huisvestingsproblemen gediscussieerd. Geen van de regelmatige publicaties van de vereniging uit de laatste eeuw ging expliciet over de ziektekostenverzekering. De rol van deze verzekering in de gezondheidszorg werd hier niet systematisch voor haar invoering bediscussieerd. Evenmin was sprake van een aansluitende evaluatie. Verder merkte de voorzitter van de vergadering in 1890, Gustav Schmoller, op dat de vereniging slechts in beperkte mate tot de sociale wetgeving had bijgedragen (Boese 1939). Historisch gezien moeten de wetenschappelijke beschouwingen van gezondheidseconomen eerder als een gevolg dan als een voorloper van de sociale ziektekostenverzekering worden gezien. Wetenschappelijk beargumenteerde voorstellen van gezondheidseconomen zijn pas recent in de gezondheidspolitieke debatten terug te vinden. In 1985, dus 112 jaar na de oproep tot haar oprichting, erkende de Verein für Socialpolitik intussen tot de grootste vereniging van Duitse economen uitgegroeid - in haar jaarvergadering de gezondheidseconomie als wetenschappelijk vakgebied (Gäfgen 1986). 
Het tweede voorbeeld betreft een zeer gevoelig, maar tegelijkertijd in vele economische redeneringen ook relevant thema, namelijk het thema van de waardering van een menselijk leven. In 1930 berekenden Dublin en Lotka de economische kosten van een vroegtijdige dood door het potentiële inkomen over de rest van het leven te meten (Dublin et al. 1946). Beschouwingen over de waarde van een mensenleven gaan eigenlijk nog veel verder in de tijd terug, minstens tot in de $17 \mathrm{e}$ eeuw tot William Petty (1623-1687). Deze Engelse arts, epidemioloog en Public Health pionier, werd precies honderd jaar voor Adam Smith (1723-1790), de grote grondlegger van de economische wetenschappen, geboren. Petty hield zich ook bezig met economische aspecten van de gezondheidszorg. Onder meer probeerde hij de kosten van de slachtoffers van de pest in Londen te schatten (Banta 1987). Daarbij was overigens nog geen sprake van een uitgewerkt meetconcept.

Het berekenen van het inkomen over het restleven veronderstelt immers een bepaald begrip van de levensverwachting. De berekening hiervan berust op het ontstaan van de waarschijnlijkheidsleer. De eerste bekende publicatie van Christian Huygens uit Leiden in het jaar 1657 hield zich bezig met de wetmatigheden van de dobbelsteen. Uit dezelfde tijd dateren ook aanzetten tot de berekening van levensverzekeringspremies (Kenessey 1993). In de huidige gezondsheidseconomie speelt het kansdenken een belangrijke rol, bijvoorbeeld bij analyses van beslissingen van individuen over de keuze tussen verzekeringscontracten of bij de waardering van de gezondheidstoestand. De oorsprong van deze toepassingen ligt in de expected utility theory, die teruggaat tot Daniel Bernoulli in de $18 \mathrm{e}$ eeuw, maar voor het eerst in 1944 door John von Neumann en Oskar Morgenstern axiomatisch exact werd geformuleerd (Schoemaker 1982). Terug nu naar de berekening van de levensverwachting. Naast de waarschijnlijkheidsleer is ook een bruikbaar sterfteregister noodzakelijk. Het begin van de routinematige registratie van sterfte moet in de $17 \mathrm{e}$ eeuw worden gesitueerd. Uit die tijd dateren ook de eerste sterftetabellen (Kenessey 1993).

Het begrip restleveninkomen als indicator voor de kosten van een vroegtijdige dood werd aan het begin van de zestiger jaren in de eerste ziektekostenstudie weer opgepakt (Weisbrod 1961). Dit begrip is tegenwoordig veelvuldig in allerlei publicaties te vinden. Niettemin moet voor een ongedifferentieerd gebruik van dit begrip worden gewaarschuwd: het begrip meet namelijk het potentiële productieverlies, de zogenaamde indirecte kosten. Het is mogelijk dat de leden van de samenleving die 
weinig of niets aan het bruto binnenlands product bijdragen worden gediscrimineerd (tenzij men bepaalde aannames maakt). In de gezondheidseconomie wordt met betrekking tot de waardering van een menselijk leven het begrip van het restleveninkomen tesamen met zijn alternatieven zowel theoretisch als empirisch bediscussieerd. Zo kan men de waarde van een menselijk leven ook meten aan de hand van verschillen in inkomen tussen meer of minder gevaarlijke beroepen of aan de hand van de bereidheid van individuen om voor de reductie van gezondheidsrisico's te betalen.

Het laatste voorbeeld legt een verband met de medische praktijk en met vragen betreffende de bedrijfsvoering in ziekenhuizen. In 1913 vroeg Codman, een arts in het Massachussets General Hospital in Boston, in een rede voor de Philadelphia County Medical Society, om een gestandaardiseerd informatiesysteem over het ziekenhuis tot stand te brengen. Doel van een dergelijk geregeld systeem was om documentatie over de gerealiseerde behandelingsresuitaten te verkrijgen en om deze informatie te gebruiken voor de verbetering van het klinisch management en de doelmatigheid van de ziekenhuiszorg (Codman 1914). Deze vooruitziende verlangens kunnen ook heden ten dage nog niet volledig worden gerealiseerd, ofschoon wij op dit punt veel verder zijn gekomen door de vooruitgang in de ziekenhuisinformatiesystemen en door de ontwikkeling van instrumenten voor de meting van de kwaliteit van het ieven.

De betekenis van de ziekenhuisdocumentatie voor een goede bedrijfsvoering is natuurlijk al veel langer bekend. Medische historici wijzen ons daarbij op de oorspronkelijke betekenis van het griekse woord oikovouia, de gezinshuishouding. Oikovouía werd ook als begrip voor de ziekenhuiseconomie gebruikt die in de $12 \mathrm{e} / 13 \mathrm{e}$ eeuw als een zelfstandige instituut tot ontwikkeling kwam. Reeds uit de $13 e$ eeuw dateert documentatie van een ziekenhuis in Barcelona over het aantal verzorgde patiënten, de aard van de ziekte, de duur van het verblijf en de medische behandeling (Schipperges 1990). Een dergelijke data-verzameling biedt eigenlijk de grondslag voor moderne patiënten-classificatiesystemen die kunnen worden ingezet voor management doeleinden. Helaas is ons het toenmalig gebruik van de gegevens niet bekend. Tegenwoordig spelen economische vraagstukken over het management van ziekenhuizen vanwege de strakke budgettering een belangrijke rol. Dit geldt zowel voor de praktijk van de bedrijfsvoering als voor de afstudeerrichting Beleid en Beheer van de Gezondheidszorg hier te Maastricht. 
Samenvattend kunnen we constateren, dat er voorbeelden bestaan van gezondheidseconomisch relevante denkbeelden uit vroegere tijden, onder andere op het gebied van de sociale politiek, de waardering van het menselijk leven en op het gebied van medisch-economische vraagstukken in het ziekenhuismanagement.

De definitieve ontwikkeling van de gezondheidseconomie - daarover zijn deskundigen het eens - begon pas in de jaren zestig en dan ook nog in het engelstalig spraakgebied. Deze ontwikkeling werd door economen in gang gezet die zich niet in de eerste plaats bezig hielden met vraagstukken van gezondheid en verzorgingssystemen, maar die op zoek waren naar interessante toepassingsgebieden. Die waren in de gezondheidszorg rijk voorradig. Hier moet in het bijzonder Kenneth Arrow genoemd worden, die tot de beroemdste hedendaagse economen wordt gerekend. In een lucide bijdrage vatte Arrow in 1963 de specifieke economische kenmerken van de markt voor gezondheidszorg samen. Deze kenmerken zijn ook tegenwoordig nog in de inleidende hoofdstukken van de leerboeken terug te vinden. Bijvoorbeeld de rol van de arts als zaakwaarnemer van de patiënt die in tegenstelling tot de soeverein en rationeel beslissende consument in het zuivere marktmodel slechts over ontoereikende informatie beschikt; of het fenomeen van de moral hazard op het gebied van de verzekeringen waarbij het optreden van schade door de verzekeringnemer wordt beïnvloed. Hiervan is bijvoorbeeld sprake wanneer een volledig verzekerde patiënt voor een kleinigheid de arts bezoekt. In een passage over de theorie van de ideale ziektekostenverzekering merkte Arrow op dat hij de lezers naar geen enkele bron kon verwijzen waarin de aan de orde zijnde grondprincipes zo omvattend behandeld werden. De ziektekostenverzekering was dus reden voor de verdere uitwerking van de verzekeringsleer.

Het ligt niet in mijn bedoeling om de verdere ontwikkeling van de gezondheidseconomie gedetailleerd te behandelen. Ik verwijs hier slechts naar de uitstekende verzameling van opstellen door Anthony Culyer (1991) die een overzicht biedt van de meest essentiële bijdragen uit de afgelopen 25 jaar. Bij wijze van voorbeeld wil ik slechts enkele thema's uit deze verzameling noemen: ziekenhuiskostenfuncties die geschat werden om de doelmatigheid of een optimale bedrijfsgrootte te bepalen; het gebruik van gezondheidsvoorzieningen afhankelijk van eigen bijdrage-regelingen londerzocht met behulp van experimentele economie); het omstreden fenomeen van de door de arts geïnduceerde vraag naar gezondheidszorg; of bijdragen tot de economische evaluatie van medische interventies, voor 
sommigen van $U$ beter bekend onder het trefwoord medical technology assessment. De ontwikkeling van de gezondheidseconomie leidde in 1980 tot het eerste wereldcongres dat in Leiden werd georganiseerd IVan der Gaag 19811. Ondanks een snelle groei van het aantal publicaties werd, ook al vanwege de diversiteit van het vakgebied, een tweede wereldcongres pas tien jaar later georganiseerd (Zweifel et al. 1992). De Rijksuniversiteit Limburg, zo kan men concluderen, behoort met de instelling van een eigen leerstoel op het gebied van de gezondheidseconomie in het jaar 1979 tot de pioniers bij de institutionalisering van het vakgebied in Europa.

Een definitie van de gezondheidseconomie

Wat is nu gezondheidseconomie en wat is de plaats ervan? Heel consequent volgens haar economische traditie wordt de gezondheidseconomie vaak gedefinieerd als de toepassing van economische begrippen en methoden op vraagstukken betreffende de gezondheidszorg. Deze definitie lijkt om twee redenen niet erg bevredigend. Ten eerste zegt de definitie weinig over de inhoud van het deelgebied en ten tweede biedt zij geen ruimte voor de ontwikkeling van eigen gezondheidseconomische begrippen en methoden. Ik wil daarom een definitie formuleren die probleemgestuurd is:

De gezondheidseconomie houdt zich bezig met de economische aspecten van gezondheid en gezondheidszorg. Dit kan door twee vragen nader worden gepreciseerd:

1. Wat zijn de economische gevolgen van ziekte en hoe wordt gezondheid op individueel en maatschappelijk niveau geproduceerd? In het bijzonder: hoe wordt de gezondheidsstatus alsmede een verandering daarin bijvoorbeeld door medische interventie, gemeten en gewaardeerd?

2. Hoe zijn volgens economisch gezichtspunt gezondheidszorgsystemen opgebouwd, hoe functioneren de voorzieningen- en financieringssystemen, hoe kunnen deze worden gestuurd, hoe hangen zij samen met andere delen van het gezondheidssysteem, en hoe kan men deze systemen economisch waarderen, in het bijzonder met behulp van de criteria doelmatigheid, rechtvaardigheid, kostenontwikkeling en bijdrage aan de productie van gezondheid? 
Deze tweede vraag omvat de reeds genoemde bedrijfseconomische probleemstellingen omdat zorginstellingen en verzekeraars onderdeel vormen van het voorzieningen- en financieringssysteem. Het zorgsysteem draagt tot de productie van gezondheid bij; dus zijn beide vragen ook met elkaar verbonden.

Het hier gedefinieerde inhoudelijke raamwerk kan natuurlijk op allerlei mogelijke manieren worden uitgewerkt. Ik wil voor elk van beide vragen enige benaderingen aar. de hand van een voorbeeld tonen.

In de eerste figuur worden de gevolgen van ziekten en de productie van gezondheid vanuit een Public Health perspectief behandeld.' In het bovenste deel van de figuur staan de oorzaken, het optreden en het verloop van ziekten als epidemiologische categorieën voor de beschrijving van het ziekteproces weergegeven. Op het niveau van de bevolking hangen deze categorieën in het bijzonder samen met de demografische ontwikkeling. Het ziekteproces kan door gezondheidspolitieke of medische interventies worden beïnvloed. Het gebruik van hulpbronnen bij een interventie hangt wederom met het zorgsysteem samen. De ziektegevolgen omvatten de beide output-dimensies: de gezondheidstoestand die de morbiditeit en mortaliteit omvat, en de kosten van interventies. De dimensie gezondheidstoestand vormt ook de volume-basis voor de indirecte kosten, dus het door ziekte en mortaliteit veroorzaakte verlies aan productie. Tezamen leveren de medische behandelingskosten en de indirecte kosten de zogeheten maatschappelijke kosten op.

Beschouwt men nu in het kader van een clinical trial de incrementele kosten van veranderingen in de gezondheidstoestand die een nieuwe medische benadeling in vergelijking tot een reeds bestaande behandeling veroorzaakt, dan gaat het om een economische evaluatie of een medical technology assessment-studie. Het onderzoek van de economische kosten van een bepaalde ziekte typeert men als een cost-of-illness studie. Rekent men op populatieniveau tot de ziektekosten ook nog de effecten van de behandeling op de gezondheidstoestand, dan verkrijgt men disease-policy models. Methodisch gaat het daarbij veelal om scenario-studies. Indien de modellering het totale ziektespectrum betreft zou men van public-health modeling kunnen spreken.

1 Tot de productie van gezondheid behoort ook een benadering vanuit het gezichtspunt van het individu, namelijk het thema van de individuele vraag naar gezondheid. Op dit thema wordt hier niet verder ingegaan. 
Figuur 1: Gevolgen van ziekte en produktie van gezondheid

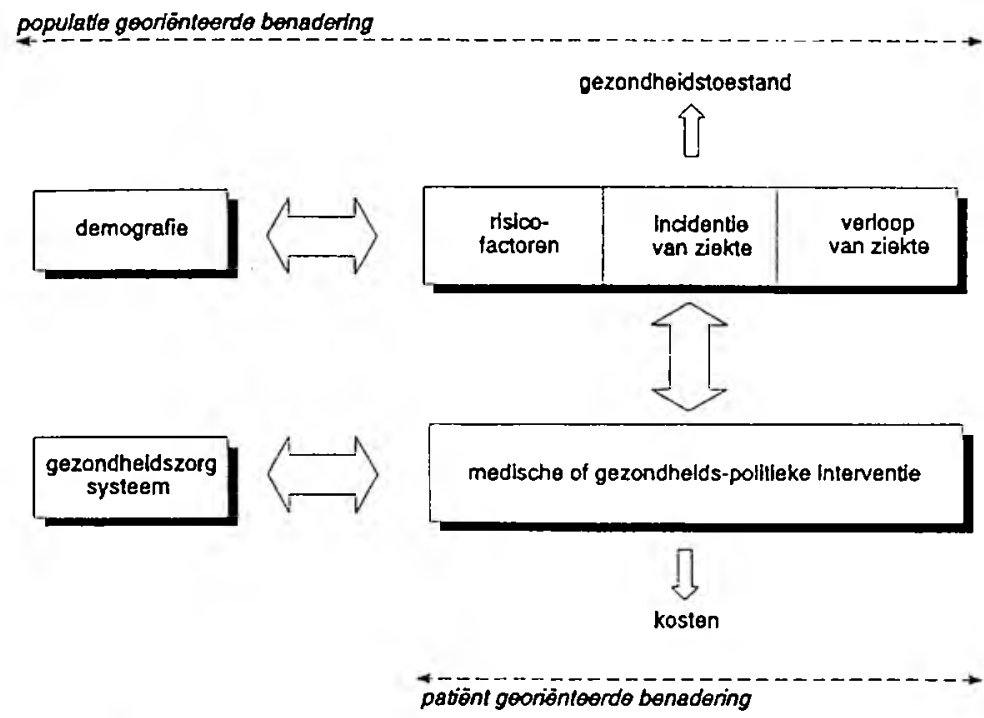

Deze verschillende benaderingen dragen bij tot het wetenschaps-theoretisch positieve economische probleem, namelijk hoeveel hulpbronnen de samenleving voor de zorgverlening aan bepaalde patiënten ter beschikking stelt en hoeveel hiermee aan verbetering van de gezondheid wordt bereikt. Daarbij gaat het dus om een analyse van de productie van gezondheid. Een normatieve vraag daarentegen is, hoeveel hulpbronnen de samenleving voor deze patiënten ter beschikking zou moeten stellen, een en ander in vergelijking tot de zorgverlening aan patiënten met andere ziekten. Een behandeling van dit normatieve probleem kan beslissingen over de allocatie van uitgaven voor gezondheidszorg ondersteunen. Van een representatieve en kwantitatieve beantwoording van deze vragen zijn wij voor wat betreft de meeste gezondheidsproblemen en de behandeling daarvan echter nog ver verwijderd.

Op dit moment zijn wel partiële bijdragen mogelijk. Dit is geenszins een marginale activiteit. Zo bevindt zich het onderzoeksgebied van de economische evaluatie in een adembenemende expansiefase: werden tussen 1970 en 1974 slechts 56 studies gepubliceerd, tussen 1990 en halver- 
wege 1992 waren dat er reeds 553 studies, dus bijna tienmaal zoveel (Backhaus et al. 1992). Verder staat dit studiegebied in enige landen op het punt een regelmatig onderdeel te worden van de toelating van geneesmiddelen (Detsky 1993, Henry 1992). De systematische uitbreiding van de kennis over de effectiviteit en efficiëntie van medische zorg kan als een grote interdisciplinaire opgave worden beschouwd waaraan de gezondheidseconomie meewerkt. Voor een omvattende micro-beschrijving van de productie van gezondheid moeten echter nog grote standaardiseringsproblemen worden opgelost. De beschikbare studies werken namelijk met nogal verschillende methoden bij de meting van de effectiviteit van interventies, vooral bij de meting van de gezondheidstoestand, maar ook bij de meting van de kosten. Standaardiseringsvraagstukken worden door onderzoeksgroepen in Nederland op nationaal en in de EEG op internationaal niveau bediscussieerd; hieraan werkt ook de vakgroep Economie van de Gezondheidszorg mee.

Wij komen nu bij een tweede afbeelding, het gezondheidssysteem. Deze afbeelding omvat het zorgverleningssysteem en zijn determinanten, alsmede de factoren die vanuit de omgeving van invloed zijn op de gezondheid, zoals de genetische dispositie, de levensstijl en het milieu. Centraal staat het zorgverleningssysteem lzie Leidl 1983, voor een concept van dit systeem voor de beschrijving van ziekenhuisfinanciering).

Op een gewone goederenmarkt staan twee partijen, namelijk vragers en aanbieders, tegenover elkaar. In het zorgverleningssysteem zijn vier actoren op twee markten met elkaar verbonden:

- Gezondheidsvoorzieningen worden door de aanbieders van zorg tot stand gebracht, door de patiënten benut, en deels door de patiënten zelf, deels door andere financiers betaald.

- De financiers ondersteunen de consument bij de financiële afdekking van ziekterisico's of zij nemen in het algemeen de zorgverlening zelf voor hun eigen rekening; ze herfinancieren hun uitgaven door premiebetaling van de verzekerde of door belastingbetaling door de burger.

De beide markten voor de zorgverlening en financiering worden gewoonlijk sterk beïnvloed door regulerende instituties, bijvoorbeeld door de koepelorganisaties, door zelfstandige bestuursorganen of door de overheid. De aanduiding 'markt' moet daarbij niet als een concurrentiemarkt worden opgevat; zij duidt slechts de plaats aan waar prestaties en tegenprestaties tegen elkaar geruild worden. 
Figuur 2: Het systeem van de gezondheidszorg
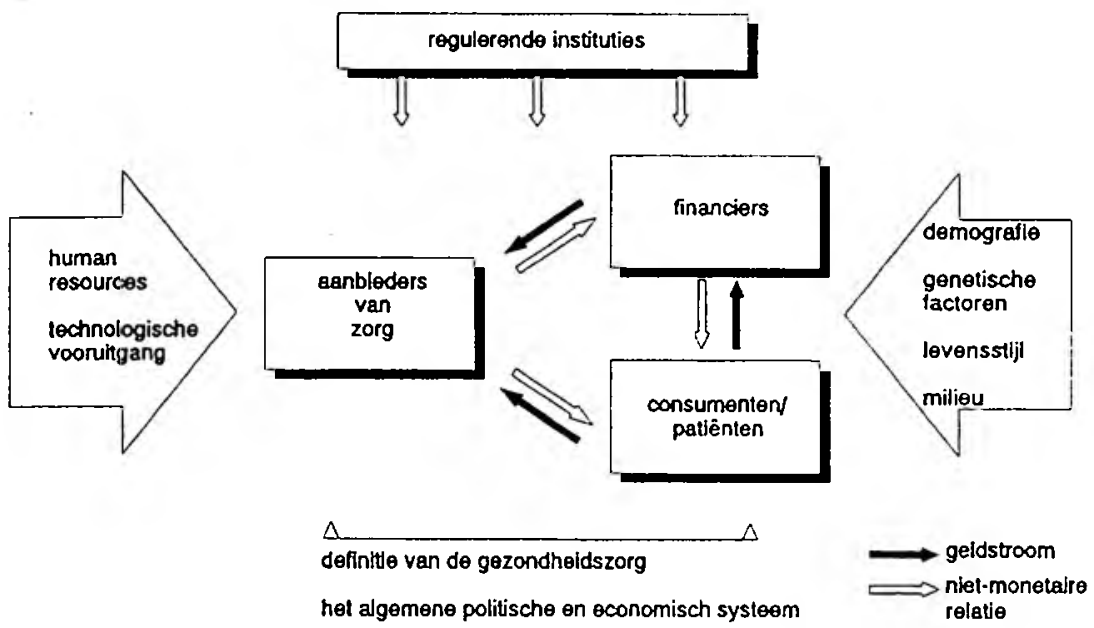

Deze fundamentele economische betrekkingen binnen het zorgverleningssysteem moeten voor een bepaalde vraagstelling nader worden gespecificeerd en uitgewerkt. Dat betreft om te beginnen de instituties die de bovengenoemde functies in de praktijk vervullen. In sommige sociale verzekeringssystemen wordt de financiering gedeeltelijk door een sociale ziektekostenverzekering en gedeeltelijk door een particuliere ziektekostenverzekering gerealiseerd; wij hebben dan twee typen van financiers. Indien de gemeentelijke gezondheidsdienst uit de belastingmiddelen wordt gefinancierd, dan komt er nog een derde type bij. Het is dus niet zo dat financiers altijd volgens het verzekeringsprincipe werken.

In een national health service, zoals bijvoorbeeld de Engelse National Health Service oude stijl, zijn zorgverlening en financiering bij de overheid bijeengebracht en met elkaar versmolten. Een essentieel onderdeel van de hervorming van de NHS die in 1991 in gang is gezet betrof de scheiding van beide functies, zodat nu de overheidsorganen als inkopers van zorg optreden. Het aanbod van verzekering en zorgverlening wordt ook geïntegreerd bij de zogeheten health maintainance organizations, voornamelijk een Amerikaanse organisatievorm; hier heeft de integratie plaats bij een 
particuliere eigenaar. Het is vanzelfsprekend dat het zorgverleningssysteem niet alleen maar één organisatietype behoeft te omvatten.

Een andere vorm van nadere uitwerking betreft de zorgverlening naar sector: typische voorbeelden zijn de ziekenhuiszorg, de ambulante zorgverlening of de zorgverlening in de vorm van genees- en andere hulpmiddelen. Gewoonlijk kennen deze deelmarkten hun eigen vergoedingssysteem zoals bijvoorbeeld de globale budgettering voor ziekenhuizen, de vergoeding per patiënt voor huisartsen en de vergoeding per verrichting voor specialisten, en de vergoeding door middel van vaste prijzen voor geneesmiddelen. Het onderzoek naar de effecten van de incentives van vergoedingssystemen vormt een klassiek domein van de gezondheidseconomie. Bij de vergoedingssystemen vinden wij overigens weer verzekeringselementen. Een aanbieder die volgens een systeem van vaste bedragen wordt betaald neemt alle financiële risico's van de variatie in verrichtingen op zich. De deelmarkten kunnen verder op allerlei mogelijke manieren worden gefinancierd - zoals bijvoorbeeld de financiering van specialistische zorg via de ziektekostenverzekering en de financiering van geneesmiddelen via de belastingen. Tenslotte is een belangrijk afgrenzingsprobleem, welke vormen van zorg nog tot het zorgverleningssysteem behoren. Zo wordt in bepaalde landen verpleeghuiszorg tot het zorgverleningssysteem gerekend, terwijl zij in andere landen daarvan wordt uitgesloten.

Deze korte beschouwing over een hoofddeel van het gezondheidssysteem, namelijk het zorgverleningssysteem, toont de veelvoud aan mogelijkheden van de economische organisatie. Daarbij zijn wij nog niet eens begonnen om een onderdeel van een concreet gezondheidssysteem volledig institutioneel te beschrijven en de bestaande regelgeving in dit systeem uit te werken. De theoretische en empirische analyse van organisatievormen van zorgverleningssystemen en de mogelijkheden om deze te hervormen zijn een belangrijke taak voor de gezondheidseconomie.

In de figuur zijn aan beide kanten van het hoofdgebied verdere invloedsfactoren ingetekend. Aan de aanbodzijde vinden wij hier de ontwikkeling van de human resources, zoals het aantal artsen, en de algemene technologische vooruitgang, bijvoorbeeld op het gebied van de informatietechnologie. Om redenen van tijd wil ik hier alleen op de tegenoverliggende vraagzijde ingaan. Bovenaan staat de demografie die als uiteraard belangrijke kostenfactor algemeen is geaccepteerd. In tegenstelling tot deze opvatting kan men aantonen, dat de te verwachten demografische 
veranderingen relatief maar in beperkte mate bijdragen aan de kostenstijging (Leidl 1992). De toenemende intensiteit van de zorgverlening blijkt veel belangrijker. Een volgend punt betreft de genetische factoren waarvoor systematische economische analyses tot dusver ontbreken. Het wekt daarentegen verbazing dat relatief weinig economische studies gewijd zijn aan het thema van de levensstijl; een gedeeltelijke uitzondering betreft daarbij roken. Het economischo gezichtspunt laat zich nog het beste verduidelijken aan de hand van de titel van een bijdrage die in 1989 in het Journal of the American Medical Association is gepubliceerd: "The Taxes of Sin: Do Smokers and Drinkers Pay Their Way?" (Manning et al. 1989). De laatste factor betreft het milieu. Gegeven het algemene milieubewustzijn en het bestaan van een aparte economie van het milieu, is het tamelijk verrassend dat vanuit gezondheidseconomisch gezichtspunt nauwelijks iets te vinden valt over milieuproblemen. Een systematische studie wordt op dit moment door een groep van Engelse economen voor het Bureau van de World Health Organization in Kopenhagen uitgevoerd.

Methoden van de gezondheidseconomie en haar betrekkingen met andere disciplines

Wij komen nu toe aan de methoden van de gezondheidseconomie alsmede haar betrekkingen met andere disciplines. In principe beschikt de gezondheidseconomie niet over een eigen methode, maar vormt zij een toepassingsgebied voor een veelvoud aan economische analytische concepten en werkwijzen. Deze heterogeniteit heeft thematische oorzaken. De gezondheidseconomie kan zich net zo goed bezighouden met de kosten-effectiviteit van gedragstherapeutische interventies bij incontirientieproblemen als met de gezondheidseffecten van economische recessies. Bij de genoemde voorbeelden zijn het welvaartseconomische en het conjunctuur-theoretische instrumentarium nodig. Daarbij komen nog de werkwijzen voor de empirische meting alsmede de integratie van medische en gezondheidswetenschappelijke aspecten. Met het oog op een systematisch overzicht wil ik eerst deelgebieden van de economie die voor de gezondheidseconomie van belang zijn behandelen en daarna de verhouding tot aangrenzende vakgebieden.

We beginnen met de economie. Haar theoretisch en empirisch instrumentarium vormt de basis voor de gezondheidseconomische analyse. Het is niet mogelijk om hier alle relevante gebieden op te noemen. Het volgende 
overzicht beperkt zich tot de belangrijkste gebieden en bouwt, met enkele modificaties, voort op een indeling van Andersen en von der Schulenburg (1991):

- De micro-economie biedt het instrumentarium voor de analyse van het economische gedrag van dokters, ziekenhuismanagers en patiënten. Verder vormt zij de grondslag voor de welvaartseconomische beoordeling van de allocatie van hulpbronnen. Als specifieke gebieden kan men ook de theorie van de industriële organisatie die de opbouw, het verloop en resultaat van markten bestudeert, alsmede de speltheorie die het strategisch gedrag onder onzekerheid onderzoekt, toevoegen.

- De openbare financiën houdt zich bezig met de economische activiteit van de overheid waartoe ook para-fiscale instituties, zoals de sociaalverzekering behoren. Tot de thema's van de openbare financiën rekent men ook de analyse van inkomsten en uitgaven in samenhang met zorgverlening alsmede de vormgeving en regulering van het zorgverleningsproces door de overheid; verder ook de methoden die ten grondslag liggen aan de economische componenten van de medical technology assessment. Bovendien valt hier de public choice benadering te noemen waarmee collectieve beslissingsprocessen, die zich in een nietmarktsituatie afspelen, kunnen worden geanalyseerd. Het gaat hierbij om een belangrijk aspect, gezien de zich voortdurend verder ontwikkelende organisatie van het gezondheidssysteem.

- De verzekeringswetenschap, een ander deelgebied van de economie, houdt zich bezig met het keuzegedrag onder onzekerheid, met het bepalen van risico's en met de verzekeringstechnische afdekking alsmede met de regulering van het verzekeringswezen.

- De bedrijfseconomie behandelt de vragen van organisatie en leiding van bedrijven, waar onder planning, financiering, marketing en controlling. In de wetenschappelijke gezondheidseconomische discussie heeft de bedrijfseconomie tot dusverre geen dominante rol vervuld, maar met de toenemende budgettering van de aanbieders en combinatie met een grotere eigen verantwoordelijkheid zal de betekenis ervan in de toekomst toenemen.

In de Duitse gezondheidseconomie wordt door sommigen ook nog de zogeheten "Ordnungspolitik" als relevant deelgebied van de economie genoemd, maar dat is meer een nationale bijzonderheid. De Ordnungspelitik houdt zich bezig met het institutionele raamwerk van de economie, in het bijzonder met de rol van marktwerking alsmede sturing door middel van koepelorganisaties en planning. De Ordnungspolitik biedt evenwel geen algemeen geaccepteerd en uitgewerkt theoretisch kader ten behoeve 
van vergelijkende analyses van verschillend georganiseerde gezondheidssystemen.

Als een apart economisch methodisch vakgebied kan verder de econometrie worden genoemd die zich bezig houdt met de identificatie en meting van functionele samenhangen tussen economische variabelen. De econometrie werd in het begin door Amerikaanse gezondheidseconomen als de centrale verbindende empirische methodiek beschouwd (Feldstein 1975). De huidige empirische gezondheidseconomie maakt weliswaar ook gebruik van de econometrie, maar daarnaast ook van simulatie-methoden of van methoden van het empirisch sociaal-wetenschappelijk onderzoek. Daarbij worden ook primaire data verzameld. Een voorbeeld betreft de meting van de gezondheidstoestand, waarbij een beslissende rol wordt gespeeld door de constructie van indicatoren, door ondervragingstechnieken en door data-verzameling.

Uit dit veelzijdig aanbod van theoretische benaderingen ontstaat een rijk toepassingsgebied voor de economische disciplines. Van haar kant moet zich een zelfstandige gezondheidseconomie bij de toepassing van methoden steeds met de nieuwste ontwikkelingen vertrouwd maken. Hier ligt dan een bepaalde spanning tussen interdisciplinaire integratie en disciplinaire vooruitgang.

Om de productie van gezondheid alsmede de organisatie van het gezondheidssysteem te kunnen analyseren is het algemene economische instrumentarium onvoldoende. Voorbeelden waarvoor de ontwikkeling van aparte gezondheidseconomische methoden noodzakelijk is, zijn:

- De meting van de gezondheidstoestand en de waardering ervan, de zogenaamde utiliteiten. Een bekende toepassing betreft de qualityadjusted life years (OALYs) die een verrekening tussen personen en tussen effecten van verschillende medische ingrepen mogelijk maken.

- De meting van het product patiëntenzorg in een ziekenhuis, bijvoorbeeld door het Amerikaanse systeem van Diagnosis-related groups, waarmee patiënten in medisch zinvolle en economisch homogene groepen kunnen worden ingedeeld (Fetter et al. 1980; Leidl et al 1990).

- De bepaling van efficiënte en rechtvaardige methoden voor de verevening van structurele verschillen in risico's tussen ziektekostenverzekeraars, bijvoorbeeld op basis van gedifferentieerde risico-indicatoren en een marktgeoriënteerde regulering van de verzekeraars, zoals voor de hervorming van de Nederlandse gezondheidszorg is voorgesteld (Van de ven et al. 1992). 
In wat nu volgt wil ik de relatie van de gezondheidseconomie met de geneeskunde en de gezondheidswetenschappen aantonen. Economisch onderzoek naar de productie van gezondheid op individueel niveau vereist de integratie van medische vakkennis. Dat onderzoek loopt van de definitie van ziekte via de bepaling van het ziekteverloop en de interventiemogelijkheden tot de resultaten van de behandeling. Voor de evaluatie van de medische interventies is dan ook een nauwe samenwerking met de klinische praktijk als ook met de klinische epidemiologie onontbeerlijk. Van hun kant kunnen gezondheidseconomen methodische kennis, bijvoorbeeld over de waardering van de gezondheidstoestand, bij de beoordeling van de effectiviteit van behandelingen inbrengen. Op het niveau van de bevolking is voor het gezondheidseconomisch onderzoek de samenwerking met de epidemiologie vereist, en soms ook met de demografie.

Voor de economische analyse van een zorgverleningssysteem is gedetailleerde kennis over de instituties noodzakelijk; daartoe behoort de basiskennis over de juridische en de politiek-organisatorische aspecten. Vandaar dat een goede samenwerking met het gezondheidsrecht en de beleidswetenschap als 'buur-disciplines' onontbeerlijk is. De empirische analyse van gezondheidszorgsystemen of instellingen maakt ook gebruik van informatiesystemen. Evenals bij de constructie van simulatiemodellen moet hier de expertise van de medische informatica worden ingebracht.

In haar vraagstellingen vereist de gezondheidseconomie dus een brede vakkennis en een nauwe samenwerking met de aangrenzende disciplines. Bijna niemand kan in alle facetten van het vakgebied deskundig zijn. Men zou de gezondheidseconomie daarom ook kritisch als een 'fuzzy set' kunnen karakteriseren. Deze term uit de informatica beschrijft een verzameling waarvan de elementen met een bepaalde mate van waarschijnlijkheid, die echter kleiner kan zijn dan 1, behoren tot de verzameling.

Met het oog op de vele theorieën en methoden die in de gezondheidseconomie worden toegepast wekt het nauwelijks verbazing, dat men dit vakgebied in verscheidende faculteiten aantreft. Daartoe behoren de economie, de geneeskunde en natuurlijk de gezondheidswetenschappen. Hier aan de Rijkuniversiteit Limburg is de gezondheidseconomie een echt, zelfstandig en integraal onderdeel in hat orkest van de public-health sciences. 


\section{Onderzoeksvoorbeeld I: HIV en AIDS}

Het eerste voorbeeld van actueel onderzoek dat ik wil bespreken betreft het thema HIV en AIDS. Dit thema behoort tot het onderzoek naar de gevolgen van ziekten en productie van gezondheid.

Op 22 december 1989 nam de EEG-Ministerraad een resolutie aan over de strijd tegen AIDS, waarin onder het hoofdstuk onderzoek onder meer werd opgeroepen tot "Analyses van de sociaal-economische gevolgen en toekomstvoorspellingen en scenario's" (Official Journal of the European Communities 1990). Deze oproep vloeide voort uit de grote onzekerheid over de toekomstige epidemiologische ontwikkelingen van AIDS, maar ook over de daarmee verbonden aanspraken op gezondheidszorg. In april dit jaar werden voor de eerste keer, met de nodige methodische voorbehouden, resultaten van een scenario-analyse op EEG-niveau gepubliceerd. Er werd berekend, dat patiënten met volledig ontwikkelde AIDS in 1995 behoefte zullen hebben aan maximaal iets minder dan 0,5\% van alle in de EEG aanwezige ziekenhuisbedden. Het te verwachten aandeel van de totale uitgaven voor gezondheidszorg in de EEG werd met 0,15 tot $0,30 \%$ aangegeven (Postma et al. 1993). Deze resultaten vloeiden voort uit een samenwerking tussen twee EEG-onderzoeksprojecten: de concerted action inzake statistische analyse en wiskundige modellering van AIDS onder leiding van het Rijksinstituut voor de Volksgezondheid en Milieuhygiëne te Bilthoven, en de EEG-studie over economische aspecten van AIDS en HIV-infectie, uitgevoerd op mijn vroegere werkplek, het Institut für Medizinische Informatik und Systemforschung (MEDIS) in Neuherberg/München, Duitsland.

Hierna wil ik enkele stappen beschrijven die voor het verkrijgen van de bovengenoemde resultaten gezet moesten worden. HIV-infectie en AIDS zijn juist daarom methodisch interessant, omdat het om een besmettelijke ziekte gaat en dientengevolge het aantal patiënten aanzienlijk kan veranderen. Inschattingen van economische gevolgen op populatie-niveau moeten ook de modellering van de epidemiologische ontwikkeling erbij betrekken. Een eerste startpunt biedt de epidemiologische berichtgeving, in dit geval dus het aantal officieel geregistreerde AIDS-gevallen. Deze cijfers moeten nog gecorrigeerd worden voor de geschatte reporting-delays. Verder moet de ontwikkeling van de HIV-infecties die tot deze AIDS-incidenties hebben geleid worden gemodelleerd. Dit maakt weer een kwantitatieve beschrijving van de ziekte-ontwikkeling noodzakelijk. De epidemiologische onderdelen van het model moeten op elkaar worden afgestemd en zo 
worden ingesteld, dat ze de waar te nemen ontwikkelingen in een populatie weerspiegelen. Slechts door een dergelijke modellering zijn een beschrijving en korte termijn prognose van het aantal patiënten met AIDS en het aantal patiënten in de daaraan voorafgaande ziektestadia mogelijk.

In aansluiting op de cijfers over de patiënten in de verschillende ziektestadia kunnen dan de economische gevolgen beschreven worden. Hiertoe behoren onder meer de verloren levensjaren, de behoefte aan ziekenhuisbedden en uitgaven voor gezondheidszorg. Om de gevolgen van ziekten in het model te integreren, moeten resultaten uit (op patiënten gebaseerde) zorg- en kostenstudies op hetzelfde aggregatieniveau gebracht worden, bijvoorbeeld op het patiëntenjaar. Het belangrijkste probleem bij een onderzoek binnen één land is om kwalitatief hoogwaardige en vooral nationaal representatieve gegevens te verkrijgen. Op het EEG-niveau komen daar nog de problemen betreffende de internationale vergelijkbaarheid bij, waaronder verschillen in zorgverleningspatronen zoals bijvoorbeeld bij de gemiddelde verpleegduur in het ziekenhuis, maar ook de omrekening van onderscheiden valuta. Op nationaal en internationaal niveau vormen de methodische verschillen in de wijze van kostenberekening ongetwijfeld het grootste probleem. Hier bestaat weer een sterke behoefte aan standaardisatie.

Alle gegevens moeten in én consistent model worden gegoten. Door de genoemde onzekerheid zijn uitvoerige analyses van de sensitiviteit van de resultaten met betrekking tot verschillende aannames noodzakelijk. Methodisch gezien kunnen de epidemiologische en economische delen van het model en de gegevens in gecomputeriseerde scenario-modellen worden geïntegreerd en verder worden verwerkt. Bij de analyse van de economische gevolgen van AIDS op het EEG-niveau werd het door mijzelf ontwikkelde software "PC-Based AIDS Scenarios" ingezet.

Nu zullen sommigen onder $u$ wel denken, er zit toch heel veel epidemiologische modellering in, de economen zullen zich beter beperken tot een gedegen meting van de kosten van behandeling van individuele patiënten en dan de kosteneffectiviteit van alternatieve strategieën van behandeling evalueren. Dit laatste liefst op basis van een gerandomiseerde clinical trial. Dat is ongetwijfeld ook noodzakelijk. Maar niet alleen bij gezondheidspolitieke vragen naar de economische gevolgen van ziekten op populatieniveau duikt de epidemiologie weer op. Bij een besmettelijke ziekte zoals HIV moet de epidemiologie ook in de economische evaluatie worden meegenomen, wanneer de medische interventie een invloed heeft op de 
niet-behandelde individuen. Dus wanneer een inenting tegen het krijgen van een ziekte beschermt en het infectiegevaar reduceert als gevolg waarvan de verspreiding van de ziekte afneemt. Of bijvoorbeeld indien een geneesmiddel de verblijfsduur in een vroeger ziektestadium verlengt zonder het infectiegevaar te reduceren, waardoor de verspreiding wordt vergroot. In het geval van HIV hangt het feitelijke effect op de verspreiding nog van een aantal andere parameters af, waarop ik hier niet verder kan ingaan. Het essentiële punt is, dat de economische evaluatie in het geval van de beschreven externaliteiten niet zonder de epidemiologische modellering kan (Leidl 1993). Voor het overige moet in genoemde situaties ook bij een voorspelling van incidenties alleen rekening worden gehouden met de omvang van de daadwerkelijke behandelingen.

Het voorbeeld AIDS toont de hoge relevantie aan tussen een goede integratie van de economische evaluatie met de epidemiologie. Populatiegerichte benaderingen die rekening houden met de epidemiologie, zijn ook relevant bij andere ziekten en interventies: Te denken valt aan de theorie van de competitieve risico's, volgens welke de onderdrukking van een bepaalde ziekte kan leiden tot een hogere incidentie van andere ziekten. Een ander voorbeeld dat populatie-gerichte informatie en modellering noodzakelijk maakt, betreft de kosten voor het inzetten van dure technologieën, zoals bijvoorbeeld medische lasers. In dit geval hangen de kosten van de behandelingen ook af van de te verwachten benutting van de capaciteit van de technologie. De populatie-gebonden aspecten spelen in een gerandomiseerde clinical trial normaal gesproken geen rol en kunnen daarin zelfs niet onderzocht worden. Om beslissingen op populatie-niveau te ondersteunen moeten dus resultaten van patiëntgerichte economische evaluatie met epidemiologische en demografische informatie alsmede met gegevens over het zorgverleningssysteem worden samengevoegd.

Op dit moment worden in Maastricht populatie-gerichte modelleringsstudies met betrekking tot AIDS, maar ook met betrekking tot hart-en vaatziekten uitgevoerd. Dit onderzoek moet $u$ ook zien in samenhang met de meer beleidsgerichte scenariostudies. Nederland beschikt met de studies van de Stuurgroep Toekomst Senario's Gezondheidszorg over een unieke traditie. Deze studies bieden een forum voor een geregelde discussie tussen de wetenschappers en de betrokken praktijkmensen en belangengroepen. Dat bevordert de praktijkrelevantie en zorgt voor een pluralistische diffusie van de studieresultaten. 
Ook de modelleringsbenaderingen zelf moeten niet opgevat worden als het streven naar een globale technocratische planning. Ze beogen veeleer de systematisering, standaardisering, aggregatie en verwerking van resultaten van studies naar ziektelast en resultaten van medical technology assessment studies. Een dergelijke kwantitatief samenvattend verwerking was ook nodig om de onderzoeksvraag van de EEGministerraad met betrekking tot AIDS te beantwoorden.

Onderzoeksvoorbeeld II: Gezondheidszorgsystemen en de Europese binnenmarkt

Het tweede voorbeeld uit lopend onderzoek heeft betrekking op gezondheidssystemen en de Europese binnenmarkt. Formeel bestaat de binnenmarkt sinds begin dit jaar. Weliswaar behoort de gezondheidszorg niet tot die markten die volgens de Europese akte van éénwording van 1985 moeten worden geïntegreerd. Bij het bekijken van de binnenmarkt kan de gezondheidszorg niet helemaal buiten beschouwing gelaten worden (Leidl 1991). Ten eerste heeft de binnenmarktpolitiek ook betrekking op de markten voor goederen- en dienstverlening die voor de gezondheidszorg relevant zijn, zoals bijvoorbeeld de markt voor geneesmiddelen en ziektekostenverzekeringen. Ten tweede kan een grotere mobiliteit binnen de gemeenschap tot een stijging van de grensoverschrijdende zorg leiden. Ten derde kan men zich afvragen, welke invloed de additionele economische groei als gevolg van de binnenmarkt op het gezondheidssysteem zal hebben. Zelfs al zouden de uitgaven voor gezondheidszorg gelijk blijven, terwijl andere economische sectoren relatief groeien, dan zou dat een fantastische bijdrage tot kostenbeheersing zijn. Natuurlijk verwacht niemand dat, maar het toont aan dat men bij het voortbestaan van nationale gezondheidssystemen er niet aan ontkomt om zich vragen over de consequenties van de binnenmarkt te stellen.

Tenslotte speelt de gezondheidszorg in de EEG geen onbelangrijke economische rol. In 1991 bedroegen de totale EEG-uitgaven bijna 8\% van het EEG-bruto binnenlands product. In orde van grootte kwam dit overeen met de waarde van het bruto binnenlands product van de zes kleinste lidstaten samen, die rond de $9 \%$ lag (berekening met koopkracht-pariteiten; OECD Health Data File 1993).

Van de vele gezondheidseconomische thema's in samenhang met de Europese binnenmarkt wil ik bij wijze van voorbeeld het probleen van de 
grensoverschrijdende zorg aandragen. Dit voorbeeld is weliswaar qua geldwaarde niet erg relevant, maar het is wel erg geschikt om economische overwegingen met betrekking tot het thema gezondheidssystemen te tonen. In tegenstelling tot de algemeen gebruikelijke nationale beschouwing van gezondheidssystemen - dat geldt overigens ook voor internationale vergelijkingen - gaat het hier namelijk om het samenspel van verschillende systemen. Grensoverschrijdende zorg betekent, dat een patiënt in één lidstaat voor ziektekosten is verzekerd of recht op zorg heeft, terwijl de zorg in een andere lidstaat geboden wordt. Een dergelijke zorgverlening kan noodzakelijk zijn in een noodsituatie tijdens een kortdurend verblijf in een ander land. Die zorg kan echter ook de reden zijn voor grensoverschrijding, namelijk bij een poging wachtlijsten te vermijden of een betere kwaliteit van zorg te verkrijgen.

In het algemeen zijn de regels voor grensoverschrijdende zorg in EEGverordeningen vastgelegd. In de praktijk bestaan er ongeveer een dozijn formulieren voor verschillende groepen van personen en doeleinden van zorgverlening. Voor grensoverschrijdende zorg die niet in een noodsituatie geboden wordt moet in het algemeen de financiering door de verzekeraar van het herkomstland van de patiënt zijn goedgekeurd. In principe verloopt die vergoeding volgens de regels van het land waar de zorg wordt aangeboden. De kosten die bij grensoverschrijdende zorg ontstaan kunnen aanzienlijk van de kosten van het land van herkomst van de patiënt afwijken. Zo bedroegen bijvoorbeeld in 1991 de uitgaven voor gezondheidszorg per hoofd van de bevolking in Nederland meer dan drie keer zo veel dan de uitgaven in Griekenland (koopkracht pariteiten). Natuurlijk zou het beter zijn de kosten van een specifieke behandeling tussen EEGlidstaten te vergelijken. Dit is echter een toekomstig onderzoeksthema; studies over dit onderwerp ontbreken nog. Methodische vragen over het vergelijken van kosten en effecten van behandelingen zijn overigens ook bij multinationale medical technology assessment-studies te vinden.

Terug naar de grensoverschrijdende zorg. In sommige systemen worden bepaalde kostenonderdelen aan de patiënt of aan de verzekeraar in rekening gebracht, zoals bijvoorbeeld investeringskosten in het ziekenhuis die in andere systemen niet door gebruikers, maar bijvoorbeeld door belastingbetalers moeten worden betaald. De combinatie van onderscheiden voorzienings- en financieringsysstemen kan dus tot afstemmingsproblemen en tot een onvoldoende of overdadige vergoeding van exploitatiekosten voeren. Verder zijn voor grensoverschrijdende zorg afrekening en tussenfinanciering door een lokale verzekeraar noodzakelijk. 
De rekeningen van de zorgverleners worden tenslotte aan centrale nationale instanties voorgelegd, daarna in Brussel gepresenteerd, en na onderhandelingen over de rechtmatigheid van de rekening vaak met lange vertragingen betaald. Verder worden deze regelingen in de lidstaten ook nog op verschillende administratieve manieren verwerkt.

Men mag verwachten dat de huidige regelingen van de grensoverschrijdende zorg met aanzienlijke efficiëntieproblemen gepaard gaan. Klaarblijkelijk treden or.vangrijke additionele kosten bij de administratieve afwikkeling op. Economen spreken hier van transactiekosten. Ten tweede kunnen de bestaande vergoedingsregels tot systematische vertekening van de prijzen van zorg voor de financiers uit het land van herkomst leiden. Ten derde zal men verwachten, dat daadwerkelijk verleende grensoverschrijdende zorg aanzienlijk groter is dan hetgeen via Brussel uiteindelijk wordt vergoed.

Gezien deze problemen wekt het nauwelijks verbazing, dat de omvang van de grensoverschrijdende zorg op het moment tamelijk gering is. De gezondheidseconomie kan tot de evaluatie van de huidige regeling bijdragen en besturingsproblemen aan het licht brengen, de tot stand gebrachte zorg en haar financiering evalueren, en proberen een niet vervulde vraag naar grensoverschrijdende zorg te identificeren. Verder kan zij alternatieve regelingen voor de toegang tot grensoverschrijdende zorg helpen ontwikkelen alsmede de financiering en de vergoeding van voorzieningen volgens economische criteria bediscussiëren.

De vragen van de grensoverschrijdende zorg behoren ook tot het thema van twee EEG-projecten, waaraan de vakgroep Economie van de Gezondheidszorg meewerkt. Verdere thema's van deze EEG-projecten zijn vergelijkende analyse van financieringssystemen in de gezondheidszorg, vergelijkingen van de uitgaven voor gezondheidszorg, vragen betreffende effecten van binnenmarktregelingen op deelmarkten en een mogelijke convergentie van de gezondheidssystemen van de lidstaten.

Een ander EEG-onderzoeksproject houdt zich specifiek met de effecten van de binnenmarkt op de markt voor geneesmiddelen bezig. De grote verschillen in prijzen van geneesmiddelen tussen de EEG-lidstaten en de ondoorzichtige nationale vergoedingssystemen en hun besturing waren voor de EEG-commissie aanleiding een transparantie-richtlijn uit te vaardigen. Door de weinig gestandaardiseerde en theoretisch niet gestructureerde antwoorden van de lidstaten werd de transparantie echter 
nauwelijks verbeterd. Daarom hoort ook de vergelijkende analyse van de nationale vergoedingssystemen tot de taken van het EEG-geneesmiddelenproject. Verder worden de effecten van EEG-richtlijnen bij de toelating en bij het op de markt houden van geneesmiddelen onderzocht. Ook aan dit project werkt de vakgroep Economie van de Gezondheidszorg mee.

Samenvattend biedt het thema EEG-binnenmarkt een aantal van onderzoeksmogelijkheden. De gezondheidseconomie kan bijdragen leveren aan theoretische en empirische economische vergelijkingen van systemen, aan de interacties tussen gezondheidssystemen en hun besturing, alsmede aan de effecten van de binnenmarktpolitiek op de afzonderlijke sectoren van gezondheidszorg.

\section{Tot besluit}

Wij zijn aan het eind van een lange reis door de gezondheidseconomie als wetenschappelijk vakgebied gekomen. De schaarste aan hulpbronnen en de economische aspecten aan gezondheid en gezondheidszorg vormden een startpunt voor het vakgebied. De gezondheidseconomie is een kind van de na-oorlogse periode. Haar wortels reiken echter tot in de tijden van het ontstaan van het sociaal-politieke denken, van de waardering van het menselijk leven, en van de geïnstitutionaliseerde zorgverlening aan zieken. De gezondheidseconomie werd gedefinieerd als de wetenschappelijke analyse van de economische aspecten van gezondheid en gezondheidszorg. Ondanks enkele aparte ontwikkelingen ligt de methodische basis van het vakgebied bij de economie en haar deelgebieden, aangevuld met bijdragen uit aangrenzende disciplines, in het bijzonder uit de geneeskunde en uit andere gezondheidswetenschappen. Aan de hand van het voorbeeld van de economische gevolgen van AIDS op bevolkingsniveau en het voorbeeld van de coördinatie van onderscheiden gezondheidssystemen in het kader van de Europese binnenmarkt werden enkele actuele onderzoeksvragen aan de orde gesteld.

De gezondheidseconomie is een veelzijdig en toegepast vakgebied die een zelfstandige rol kan spelen. Regelmatig worden van gezondheidseconomen bijdragen verwacht aan de advisering van beleidsmakers en aan de ondersteuning van besluitvorming. Daarnaast moet echter ook voldoende aandacht besteed worden aan de verdere ontwikkeling van theorieën en methoden voor de analyse van de produktie van gezondheid en van de organisatie van het gezondheidssysteem. 
Tot slot nog enkele woorden van dank. De heren prof. Wilhelm von Eimeren en prof. Detlef Schwefel zou ik graag willen danken voor de vele onderzoeksmogelijkheden en internationale contacten die zij mij gedurende mijn verblijf aan het MEDIS-Instituut in München geboden hebben.

Aan de Rijkuniversiteit Limburg wil ik in de eerste plaats het College van Bestuur en de Faculteit voor Gezondheidswetenschappen danken voor het vertrouwen dat zij in mijn persoon hebben gesteld. Ik zal mijn uiterste best doen om dat vertrouwen waar te maken. Danken wil ik ook mijn collega's aan de faculteit der Gezondheidswetenschappen, alsmede sommige collega's aan de economische faculteit en de faculteit der Algemene Wetenschappen. Zij hebben mij bij mijn entree in de Universiteit en Faculteit van harte ondersteund. Dat geldt ook voor mijn kennismaking met de organisatie en de cultuur van de universiteit en faculteit.

In het bijzonder wil ik mijn collega uit de Beleidswetenschap noemen, prof. Hans Maarse. Met narne zijn persoonlijke inzet heeft mijn start in Maastricht zeer vergemakkelijkt. Hij heeft ook grotendeels bij de vertaling van deze rede, die eerst in Duitse taal was geschreven, geholpen. Enige onderdelen heeft Maureen Rutten voor haar rekening genomen. Tenslotte wil ik alle leden van de vakgroep Economie van de Gezondheidszorg danken voor de ondersteuning die zij mij hebben aangeboden. Ik wens ons allen een produktieve tijd in onderzoek en onderwijs toe.

Ik heb gezegd en dank $U$ voor Uw aandacht.

Verdere verantwoording: Ik dank mevrouw Hilde Oostveen voor het uittypen van het manuscript en de heer Jan van Emmerik voor de productie van de figuren. Ik dank ook prof. Jürgen Backhaus van de economische faculteit, die enige bronnen over de Verein für Socialpolitik ter beschikking stelde. 


\section{Literatuur}

American Economic Association (1951) Economics of medical care. American Economic Review 41: 617-96

Andersen HH, von der Schulenburg JM (1991) Forschungsiragen und Gegenstãnde der Gesundheitsökonomie. in: Schwartz, FW. Badura, B. Brecht et al. Hrsg. Public Health. Texte zu Stand und Perspektiven der Forschung. Springer: Berlin

Arrow K (1963) Uncertainty and the welfare economics of medical care. American Economic Review 53: 841-933

Backhouse ME, Backhouse RJ, Edey SA (1992) Economic evaluation bibliography. Health Economics 1 (supplement)

Banta JE (1987) Sir William Petty: modern epidemiologist (1623-1687). Journal of Community Health 12 (2,3): 185-98

Boese F (1939) Geschichte des Vereins für Socialpolitik 1872-1932. Schriften des Vereins für Socialpolitik, Bd. 188, Duncker \& Humblot: Berlin

Codman EA (1914) The product of the hospital. Surgery, Gynecology and Obstetrics 18: 491.496

Culyer AJ ed. (1991) The economics of health. Volume I and II. The international library of critical writings in economics. Gaillard: Great Yarmouth

Detsky AS (1993) Guidelines for economic analysis of pharmaceutical products; a draft document of Ontario and Canada, Pharmaco Economics, 2: 354-361

Dublin LI, Lotka AJ (1946) The monetary value of a man. Revised edition, Ronald Press Co.: New York

Feldstein M (1975) Econometric studies of health economics. In: Intriligator $M$, Kendrik D (eds.) Frontiers of Quantitative Economics II. Amsterdam: North-Holland Publishing

Fetter RB, Shin Y, Freeman JL, Averill RL. Thompson JD (1980) Case mix definition by Diagnosis-Related Groups. Medical Care, 18 (2) Supplement

Gäfgen G Hrsg. (1986) Ökonomie des Gesundheitswesens. Duncker \& Humblot: Berlin

Henry D (1992) Economic analysis as an aid to subsidisation decisions; the development of Australian guidelines for Pharmaceuticals, Pharmaco Economics 1: 54-67

Herder-Dorneich P (1981) Problemgeschichte der Gesundheitsökonomik. In: HerderDorneich P, Sieben G, Thiemeyer T Hrsg. Wege zur Gesundheitsökonomie I. Band 1 der Reihe Beiträge zur Gesundheitsökonomie. Gerlingen, 11-45

Kenessey $Z$ (1993) The emergence of quantitative thinking about mortality and life expectancy. Paper presented at the 5 th Heilbronn Symposium on Economics and 
the Social Sciences: Paracelsus (1493-1993) after 500 years? Heilbronn, 1-4 July

Leidl $R$ (1993) A survey of the economic evaluation of early drug intervention in HIV infection. Working towards a population-based approach. In: Kaplan \& $M$. Brandeau eds., Modeling the AIDS Epidemic, New York: Raven Press (in press)

Leidl $R$ (1992) Health economic issues relevant to countries with aging populations. World Health Statistics Quarterly, 45 1: 95-108

Leidl $R$ (1991) How will the single European market affect health care? British Medical Journal, 303: 1081-82

Leidl R, Potthoff, P, Schwefel, D eds. (1990) European approaches to patient classification systems. Methods and applications based on disease severity, resource needs, and consequences. Springer: Berlin

Leidl R (1983) The hospital financing system of the Federal Republic of Germany. Effective Health Care 1 (3): 133-142

Manning WG, Keeler EB, Newhouse JP et al. (1989) The taxes of sin: do smokers and drinkers pay their way? Journal of the American Medical Association 261: 1604-9

Mushkin SJ (1958) Towards a definition of health economics. Public Health Reports 73 (9): $785-793$

Offical Journal of the European Communities (1990) Resolution of the Council and the Ministers for Health of the Member States, meeting within the Council of 22 December 1989 on the fight against AIDS, C10/02, 33: 3-7 (16 January)

Postma MJ, Leidl R, Downs AM, Rovira J, Tolley K, Gyldmark M, Jager JC (1993) Economic impact of the AIDS epidemic in EC countries: towards multinational scenarios on hospital care and costs. AIDS 7: 541-53

Schipperges H (1990) Der Garten der Gesundheit. Medizin im Mittelalter. Deutscher Taschenbuch Verlag München

Schoemaker PJH (1982) The expected utility model: Its variants, purposes, evidence and limitations. Journal of Economic Literature 20: $529-63$

Weisbrod BA (1961) Economics of public health. Measuring the economic impact of diseases. University of Pennsylvania: Philadelphia

Van der Gaag J Perlman M eds. (1981) Health, economics, and health economics. Noth Holland Publishing Company: Amsterdam

Van de Ven WPMM, Van Vliet RCJA (1992) How can we prevent cream skimming in a competitive health insurance market? the great chalienge for the $90^{\circ} \mathrm{s}$. In: Zweifel P, Frech III HE eds. Health economics worldwide. Kluwer: Dordrecht 23-46

Zweifel P, Frech III HE eds. (1992) Health Economics worldwide. Kluwer: Dordrecht 